\title{
Do Psychological Variables Mediate Sex Differences in Young Adults' Alcohol Use?
}

\author{
Friederike Zimmermann and Monika Sieverding
}

Psychological Institute, University of Heidelberg, Germany

This study applied an extended theory of planned behavior to test whether psychological variables mediate sex differences in alcohol consumption in social contexts. Questionnaires of 300 young adults (urban, mean age 25 years, $49 \%$ female) were collected in 2007 prior to a sociable drinking occasion; consumption data were obtained through telephone interviews thereafter. The multiple-path mediation model was analyzed using structural equation modeling. Sex differences in alcohol consumption, which were considerable, were partly mediated by the significant specific indirect effects of subjective norms through intention and of self-efficacy through both intention and willingness. Body weight was not a significant mediator. Limitations are noted and implications for future research are discussed.

Keywords alcohol, young adulthood, sex/gender, theory of planned behavior, behavioral willingness, mediation

\section{INTRODUCTION}

Men consume larger amounts of alcohol and drink more frequently and more often heavily than women on average. Such sex differences in drinking behavior have been consistently found throughout countries all over the world, although varying in size across countries (Mäkelä et al., 2006; Wilsnack, Vogeltanz, Wilsnack, \& Harris, 2000; Wilsnack, Wilsnack, Kristjanson, Vogeltanz-Holm, \& Gmel, 2009). Sex differences in biological factors (e.g., body weight, proportion of body water, and ethanol metabolism) contribute to women's higher blood alcohol levels at equivalent doses compared with men (e.g., Holmila \& Raitasalo, 2005). Thus, women may abstain from "heavier" alcohol intake because they feel intoxi- cated at lower levels of alcohol exposure. Sex differences in drinking behavior may also result from psychological variables ${ }^{1}$ such as perceived social pressure to drink or perceived sanctions for drinking excessively, which are different for men and women (Suls \& Green, 2003). These differences may stem from sex-specific traditions in alcohol use corresponding to traditional gender roles. Women's primary responsibilities for child care, for example, may have contributed to social disapproval of "heavy drinking" among females (Nolen-Hoeksema \& Hilt, 2006; Waldron, 1988). In contrast, alcohol use is encouraged for men as it is linked with attributes of masculinity such as toughness and willingness to take risks (Lemle \& Mishkind, 1989; Peralta, 2007) and may be used as means of affirming one's masculinity (Courtenay, 2000).

The aim of the present study was to identify psychological mediators ${ }^{2}$ of sex differences in young adults' alcohol consumption. Previous studies that addressed this research question yielded little evidence for mediation of sex differences with regard to alcohol use (e.g., Huselid \& Cooper, 1992; Neve, Lemmens, \& Drop, 1997) and were not without their limitations: Cross-sectional designs were applied and behavior was assessed retrospectively (Huselid \& Cooper, 1992; Kahler, Read, Wood, \& Palfai, 2003; Keefe \& Newcomb, 1996; Neve et al., 1997) or only intention was used as the dependent variable (Armitage, Norman, \& Conner, 2002). We utilized a longitudinal design and measured the potential mediators of sex before we assessed the behavioral outcome.

For the theoretical foundation an extended version of the Theory of Planned Behavior (TPB, Ajzen, 1991) was used. It is a genuine mediation model, where distal factors (e.g., demographic variables like sex) are

\footnotetext{
${ }^{1}$ In the literature, it is proposed that biological and psychological factors combine to result in sex differences and in variation within the sexes in drinking behavior (Holmila \& Raitasalo, 2005; Nolen-Hoeksema \& Hilt, 2006).

${ }^{2}$ The topic of mediation is to illuminate mechanisms that account for a seemingly direct effect. In this context, this means to identify variables that explain sex differences in alcohol use. It should be noted that the investigation of mediation is different from the topic of moderation, which implies separate analyses for the sexes with the possible result of sex-specific patterns in influences on drinking. The latter question is not to be answered here but was addressed in a different paper using another theoretical approach (Zimmerman \& Sieverding, 2010).

Address correspondence to Friederike Zimmermann, Psychological Institute, University of Heidelberg, HauptstraBe 47-51, 69117 Heidelberg, Germany; E-mail: friederike.zimmermann@psychologie.uni-heidelberg.de
} 


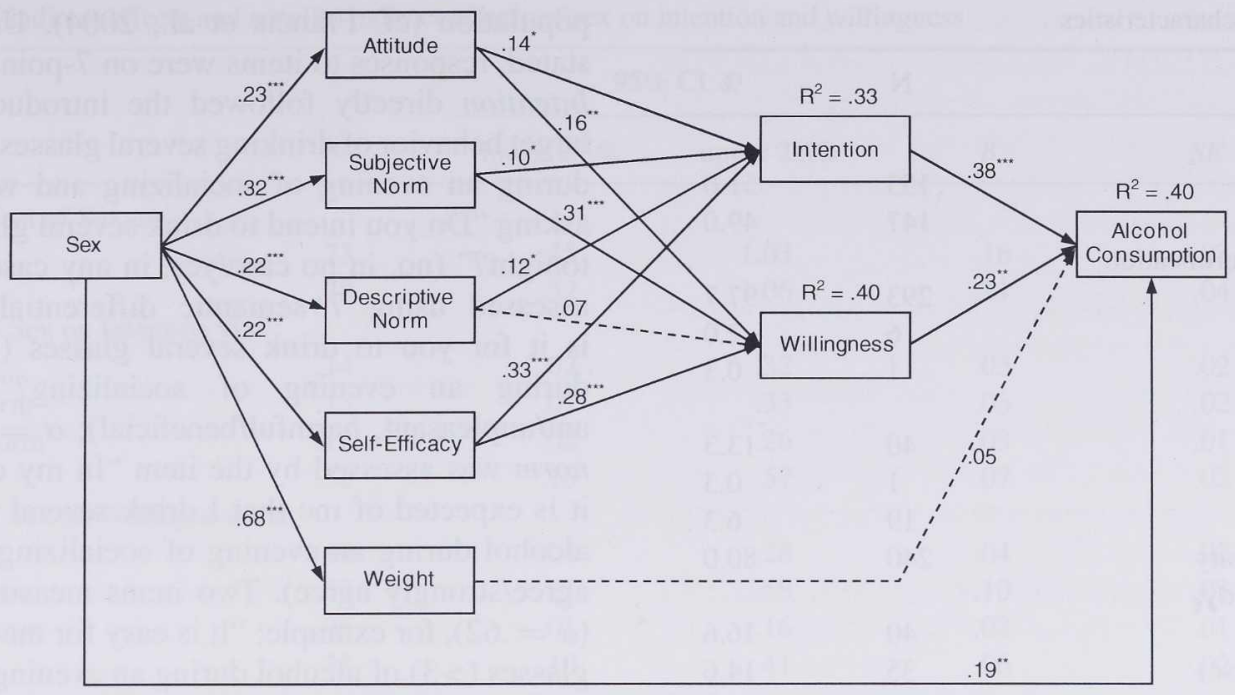

FIGURE 1. Path model showing the partial mediation of sex on alcohol consumption through an extended theory of planned behavior controlling for weight $(\mathrm{N}=300)$. Standardized path coefficients, ${ }^{*} p<.05,{ }^{* *} p<.01,{ }^{* * *} p<.001$ (two-tailed); dashed lines represent nonsignificant paths. Disturbances and correlations were modeled but not plotted. Model fit indices: $\chi^{2}=7.60, d f=10, p=.67 ; C F I=1.00, T L I=1.00$, RMSEA $=.00, S R M R=.02$.

supposed to have an indirect effect on behavior through the social-cognitive variables attitude, subjective norm, and perceived behavioral control, mediated by intention (Conner \& Sparks, 2005). Behavioral intention represents an individual's previously made decision to exert effort on a specific behavior. Attitude is the global positive or negative evaluation of performing the target behavior. Subjective norm represents the perceived social pressure of significant others to perform the behavior in question. Perceived behavioral control comprises an individual's perceived ease or difficulty of acting (related to the concept of self-efficiency, Bandura, 1977) and whether control of engaging in the behavior is up to the actor. To the extent that perceived behavioral control reflects actual control over the behavior, it should also directly influence behavior. The TPB proved to be useful in explaining drinking behavior in previous research (e.g., Conner, Warren, Close, \& Sparks, 1999).

The subjective norm, however, sometimes failed to predict intention (Collins \& Carey, 2007; Norman \& Conner, 2006). Therefore, we extended the TPB by including the descriptive norm, which reflects what is normal to be done (Cialdini, Reno, \& Kallgren, 1990), and proved to predict intentions over and above variables of the TPB (Rivis \& Sheeran, 2003). With regard to alcohol consumption, high perceived descriptive norms (Suls \& Green, 2003: Experiment 1) may mislead people to consider their own consumption as less problematic and may motivate them to match the norm by increasing their own drinking (Carey, Borsari, Carey, \& Maisto, 2006; Perkins, 2002a).

In the TPB, variables influence behavior through a deliberative, intentional process. However, alcohol consumption may be determined by a more immediate reaction to tempting opportunities, which typically arise in social drinking situations. Therefore, we further augmented the TPB by adding behavioral willingness. This con- cept is defined as openness to health-risk opportunities, which typically occur in the presence of others (Gibbons, Gerrard, \& Lane, 2003). Research has shown the independent influences through the dual processes - the reasonedaction path through intention and the social-reaction path through willingness (e.g., Gibbons, Gerrard, Blanton, \& Russell, 1998).

The path model in Figure 1 gives an impression of the hypothesized mediation model. Sex is the most distal variable and should have an indirect effect on alcohol consumption through attitude, subjective norm, descriptive norm, and self-efficacy (representing perceived behavioral control in this study) via intention and willingness. We controlled for body weight, which may contribute as a biological variable to the amount of alcohol consumed.

\section{METHOD}

\section{Participants and Procedure}

Participants were young adults aged 25 years on average $(S D=3.6$; for further sample characteristics see Table 1). Questionnaires were administered at Time 1, on Fridays and Saturdays, in cafeterias on the university campus in Heidelberg (about 140.000 inhabitants), Germany, by experienced research assistants (male and female) and the first author, who were of approximately the same age as the people approached. We focused on young adults, mainly students, who form an at-risk group (Hingson, Heeren, Zakocs, Kopstein, \& Wechsler, 2002; Perkins, $2002 b$ ) and whose drinking typically takes place in social contexts. University students and non-students differed in none of the variables studied. About $80 \%$ of the people approached were willing to take part in the study and declared to spend one upcoming weekend evening socializing. A few days after the weekend drinking opportunity, behavioral data were provided by 101 male and 101 
TABLE 1. Sample characteristics

\begin{tabular}{lrr}
\hline & $\mathrm{N}$ & $\%$ \\
\hline Sex & & \\
Male & 153 & 51.0 \\
Female & 147 & 49.0 \\
Secondary school certification & & \\
$\quad$ High track & & \\
Middle track & 293 & 97.7 \\
Low track & 6 & 2.0 \\
Occupational status & 1 & 0.3 \\
Employed & & \\
Unemployed & 40 & 13.3 \\
Training & 1 & 0.3 \\
Attending university & 19 & 6.3 \\
(Major) Field of study: & 240 & 80.0 \\
Law & & \\
Languages (diverse) & 40 & 16.6 \\
Economics & 35 & 14.6 \\
Political science & 24 & 10.0 \\
History & 18 & 7.5 \\
Physics & 17 & 7.1 \\
Psychology & 15 & 6.3 \\
Miscellaneous & & 4.6 \\
\hline
\end{tabular}

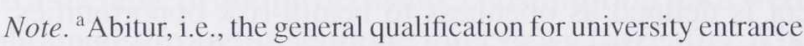
in Germany. ${ }^{b}$ for example, mathematics, sociology, ethnology, archaeology, theology, philosophy, sports, medicine.

female participants, who could be reached at Time 2 (203 by telephone, 29 by e-mail) and had actually spent an evening of socializing over the weekend. Individuals participated voluntarily and gave informed consent; confidentiality was assured and contact information was destroyed following data entry.

\section{Measures}

The social-cognitive variables assessed at Time 1 were developed based on other samples from the target population (cf. Francis et al., 2004). Unless otherwise stated, responses to items were on 7-point bipolar scales. Intention directly followed the introduction about the target behavior of drinking several glasses $(>3)$ of alcohol during an evening of socializing and was assessed by asking "Do you intend to drink several glasses of alcohol tonight?" (no, in no case/yes, in any case). Attitude was assessed using 7 semantic differential scales: "How is it for you to drink several glasses $(>3)$ of alcohol during an evening of socializing?" (e.g., pleasant/unpleasant, harmful/beneficial); $\alpha=$.85. Subjective norm was assessed by the item "In my circle of friends it is expected of me that I drink several glasses $(>3)$ of alcohol during an evening of socializing" (strongly disagree/strongly agree). Two items measured self-efficacy $(\alpha=.62)$, for example: "It is easy for me to drink several glasses ( $>3$ ) of alcohol during an evening of socializing" (strongly disagree/strongly agree). Descriptive norm was measured with the question: "What do you estimate is the percentage (from $0 \%$ to $100 \%$ ) of people in your circle of friends that consume several glasses $(>3)$ of alcohol during an evening of socializing". Two scenarios were created to assess willingness and were introduced by: "Imagine the following situations. You are out with some friends on a Saturday evening and have already consumed quite a number of alcoholic drinks. You have the impression that you drank enough"; scenario 1: "It is about midnight and someone having a birthday is paying for another round". Each scenario was followed by "I continue drinking" (no, in no case/yes, in any case); $\alpha=$ .86. Finally, background characteristics were requested.

To assess alcohol consumption at Time 2 as accurate as possible, we asked participants to recall all alcoholic beverages they had consumed and to specify the amount of each drink. Furthermore, they were asked to estimate the duration of their drinking episode. The outcome variable was the total amount of pure alcohol consumed in grams during one evening of socializing and was calculated by

TABLE 2. Means and standard deviations for the overall sample, the male and female sub-samples, and t statistics of sex differences in the study variables

\begin{tabular}{|c|c|c|c|c|c|c|c|}
\hline & \multicolumn{2}{|c|}{ Overall } & \multicolumn{2}{|c|}{ Male } & \multicolumn{2}{|c|}{ Female } & \multirow[b]{2}{*}{$t$ score } \\
\hline & $M$ & $S D$ & $M$ & $S D$ & $M$ & $S D$ & \\
\hline Attitude & 4.45 & 1.03 & 4.67 & 0.99 & 4.22 & 1.02 & $3.88^{* * *}$ \\
\hline Subjective Norm & 2.66 & 1.85 & 3.24 & 2.03 & 2.05 & 1.40 & $5.93^{* * *}$ \\
\hline Descriptive Norm ${ }^{a}$ & 76.61 & 20.77 & 81.18 & 17.26 & 71.93 & 22.92 & $3.94^{* * *}$ \\
\hline Self-Efficacy & 5.20 & 1.45 & 5.51 & 1.34 & 4.88 & 1.47 & $3.88^{* * *}$ \\
\hline Intention & 4.20 & 2.23 & 4.80 & 2.19 & 3.58 & 2.10 & $4.92^{* * *}$ \\
\hline Willingness & 3.65 & 1.83 & 4.04 & 1.91 & 3.25 & 1.66 & $3.81^{* * *}$ \\
\hline Weight (kg) & 69.86 & 13.36 & 78.58 & 11.03 & 60.53 & 8.41 & $15.98^{* * *}$ \\
\hline Alcohol Consumption $(\mathrm{g})^{\mathrm{b}}$ & 67.09 & 66.68 & 88.42 & 81.85 & 41.67 & 24.66 & $5.23^{* * *}$ \\
\hline $\mathrm{BAC}^{\mathrm{b}, \mathrm{c}}$ & 1.42 & 1.15 & 1.61 & 1.37 & 1.19 & .73 & $2.55^{*}$ \\
\hline Duration of Episode $(\mathrm{h})^{\mathrm{b}}$ & 3.99 & 2.44 & 4.37 & 2.82 & 3.54 & 1.82 & $2.32^{*}$ \\
\hline BAC $-0.1 \%$ per hour ${ }^{b}$ & 1.02 & .98 & 1.17 & 1.17 & .83 & .63 & $2.41^{*}$ \\
\hline
\end{tabular}

Note. Overall $N=300$, male $n=153$, female $n=147$. Variables range from 1 to 7 , if not otherwise indicated.

${ }^{\mathrm{a}}$ In percent from 0 to $100 .{ }^{\mathrm{b}} \mathrm{Sub}$-sample $(n=171)$ of participants who were engaged in a sociable episode and drank alcohol. ${ }^{\mathrm{c}} \mathrm{Blood}$ alcohol concentration (BAC) in permille calculated with the Widmark formula (Widmark, 1932).

${ }^{*} p<.05,{ }^{* * *} p<.001$ (two-tailed). 
TABLE 3. Total indirect effects and specific indirect effects of sex on intention and willingness

\begin{tabular}{|c|c|c|c|c|c|c|}
\hline & \multirow[b]{2}{*}{$\mathrm{B}$} & \multicolumn{2}{|c|}{$95 \% \mathrm{CI}$} & \multirow[b]{2}{*}{$\beta$} & \multirow[b]{2}{*}{$S E$} & \multirow[b]{2}{*}{$z$ score } \\
\hline & & lower $2.5 \%$ & upper $2.5 \%$ & & & \\
\hline \multicolumn{7}{|c|}{ Total indirect effect of Sex on } \\
\hline Intention & .73 & .45 & 1.03 & .16 & .03 & $5.01^{* * *}$ \\
\hline Willingness & .78 & .52 & 1.06 & .21 & .04 & $6.04^{* * *}$ \\
\hline \multicolumn{7}{|c|}{ Indirect effect of Sex on Intention via: } \\
\hline Attitude & .14 & .02 & .32 & .03 & .02 & 1.88 \\
\hline Subjective Norm & .15 & .01 & .33 & .03 & .02 & 1.83 \\
\hline Descriptive Norm & .12 & .02 & .26 & .03 & .01 & $1.93^{+}$ \\
\hline Self-Efficacy & .32 & .15 & .57 & .07 & .02 & $3.08^{* *}$ \\
\hline \multicolumn{7}{|c|}{ Indirect effect of Sex on Willingness via: } \\
\hline Attitude & .14 & .04 & .28 & .04 & .02 & $2.32^{*}$ \\
\hline Subjective Norm & .37 & .21 & .58 & .10 & .03 & $4.01^{\text {*** }}$ \\
\hline Descriptive Norm & .06 & -.01 & .16 & .02 & .01 & 1.38 \\
\hline Self-Efficacy & .23 & .10 & .41 & .06 & .02 & $2.92^{* *}$ \\
\hline
\end{tabular}

Note. $N=300$. Bootstrapped standard errors; confidence limits are based on bias-corrected bootstrap.

${ }^{+} p=.054,{ }^{*} p<.05,{ }^{* *} p<.01,{ }^{* * *} p<.001$ (two-tailed).

summing the products of number of drinks of one type of alcohol $\times$ amount in $\mathrm{ml} \times$ percent by volume $\times$ specific gravity of ethanol for each person.

\section{Data Analyses}

To analyze the hypothesized model with its multiple mediational chains, structural equation modeling with manifest variables was conducted (Kline, 2005). To handle missing data appropriately, they were treated with the model-based Full-Information Maximum Likelihood (FIML) procedure (Allison, 2003; Graham, 2009). Nonparametric resampling methods were implemented to deal with potential non-normality in the multiple-path mediation model (MacKinnon, 2008; Neal \& Simons, 2007; Preacher \& Hayes, 2008; Taylor, MacKinnon, \& Tein, 2008): As implemented in Mplus (Muthén \& Muthén, 2008) we used the bootstrap option (with 10.000 bootstrap samples) to compute standard errors and the bias-corrected bootstrap option to determine $95 \%$ confidence intervals for the specific indirect, the total effect, and the total indirect effects.

\section{RESULTS}

\section{Descriptive Findings}

Men and women differed significantly in all of the study variables (see Table 2). Eight percent of the men and $23 \%$ of the women attainable at Time 2 spent an evening of socializing and did not drink alcohol. Among those who spent an evening of socializing and drank alcohol, men consumed 7.3 drinks (given $12 \mathrm{~g}$ of pure alcohol per standard drink) in 4 hours and 22 minutes, whereas women consumed 3.5 drinks in 3 hours and 32 minutes on average.

TABLE 4. Total effect, total indirect effect, and specific indirect effects of sex on alcohol consumption ${ }^{\mathrm{a}}$

\begin{tabular}{|c|c|c|c|c|c|c|}
\hline & \multirow[b]{2}{*}{ B } & \multicolumn{2}{|c|}{$95 \% \mathrm{CI}$} & \multirow[b]{2}{*}{$\beta$} & \multirow[b]{2}{*}{ SE } & \multirow[b]{2}{*}{$z$ score } \\
\hline & & lower $2.5 \%$ & upper $2.5 \%$ & & & \\
\hline \multicolumn{7}{|l|}{ Effects of Sex on Alcohol Consumption: } \\
\hline Total effect & .44 & .31 & .62 & .34 & .04 & $8.14^{* * *}$ \\
\hline Total indirect effect & .19 & .04 & .47 & .15 & .06 & $2.31^{*}$ \\
\hline \multicolumn{7}{|c|}{ Effect of Sex on Alcohol Consumption via: } \\
\hline Attitude $\rightarrow$ Intention & .02 & .00 & .04 & .01 & .01 & 1.79 \\
\hline Subjective Norm $\rightarrow$ Intention & .02 & .00 & .04 & .01 & .01 & 1.68 \\
\hline Descriptive Norm $\rightarrow$ Intention & .01 & .00 & .03 & .01 & .01 & 1.73 \\
\hline Self-Efficacy $\rightarrow$ Intention & .04 & .02 & .07 & .03 & .01 & $2.49^{*}$ \\
\hline Attitude $\rightarrow$ Willingness & .01 & .00 & .04 & .01 & .00 & $1.93^{+}$ \\
\hline Subjective Norm $\rightarrow$ Willingness & .03 & .01 & .07 & .02 & .01 & $2.71^{* *}$ \\
\hline Descriptive Norm $\rightarrow$ Willingness & .01 & .00 & .02 & .00 & .00 & 1.25 \\
\hline Self-Efficacy $\rightarrow$ Willingness & .02 & .01 & .05 & .01 & .01 & $2.39^{*}$ \\
\hline Weight & .05 & -.08 & .28 & .03 & .06 & 0.56 \\
\hline
\end{tabular}

Note. $N=300$. Bootstrapped standard errors; confidence limits are based on bias-corrected bootstrap.

${ }^{\mathrm{a}}$ In $\mathrm{g}$ of pure alcohol.

${ }^{+} p \leq .054,{ }^{*} p<.05,{ }^{* *} p<.01,{ }^{* * *} p<.001$ (two-tailed). 
Mediation Analysis for the Effect of Sex on Alcohol Use The mediation model is given in Figure 1. Correlations of sex with intention and willingness were modeled and disturbances of the mediators were allowed to correlate (cf. Preacher \& Hayes, 2008). The model fitted the data very well (cf. Schermelleh-Engel, Moosbrugger, \& Müller, 2003): $\chi^{2}=7.60, d f=10, p=.67 ; C F I=1.00, T L I=$ $1.00, R M S E A=.00, S R M R=.02$. Most of the hypothesized single paths of the mediational chains were significant (see Figure 1). For significance of the indirect effects of sex on intention and willingness (two-path mediational chains) see Table 3 ; whether this means significant mediation of sex up to alcohol consumption (three-path mediational chains) can be seen in Table 4.

Paths of sex on attitude, subjective norm, descriptive norm, self-efficacy, and body weight were all highly significant (cf. Figure 1). The effect of sex was significantly transmitted to intention via self-efficacy; the effect of sex was significantly transmitted to willingness via attitude self-efficacy and via the subjective norm (cf. Table 3). Finally, the effect of sex on alcohol consumption was mediated by self-efficacy through intention, and by subjective norm and self-efficacy through willingness (cf. Table 4). The mediation of sex through body weight was not significant. Altogether, $44 \%$ of the effect of sex on alcohol consumption were explained by the psychological variables (i.e., the "mediation proportion", see Ditlevsen, Christensen, Lynch, Damsgaard, \& Keiding, 2005).

\section{DISCUSSION}

The present study investigated psychological processes that mediate the effect of sex on young adults' alcohol consumption. Three mediational chains were significant and partly explained the sex difference: Men had a higher subjective norm, which led to more alcohol consumption through higher willingness. Similarly, men's higher self-efficacy led to more excessive alcohol consumption through both higher willingness and higher intention. The unique indirect effects were small, but it has to be considered that with multiple-path mediation, the effect of sex on the outcome was mediated through three paths in a series, with potential "losses" from step to step, respectively. Some of the indirect effects were non-significant, despite their significant single paths (e.g., attitude through willingness, cf. Table 3 and 4), and might have perished in the context of all other variables due to a certain degree of collinearity (cf. Preacher \& Hayes, 2008).

Body weight was not a significant mediator. The remaining direct effect of sex may, however, be attributable to other biological influences related with sex. Controlling for the sex-specific proportion of body water included in the Widmark formula of blood alcohol concentration, and the metabolism of alcohol during the drinking period further reduced the sex difference in alcohol consumption (cf. Table 2). We explored the biological variables in re- analyses by including them in the outcome. ${ }^{3}$ Results were similar to those reported, and yielded a nonsignificant direct effect of sex with a mediation proportion of $71 \%$. This finding implies that the combination of biological and psychological influences largely explains sex differences in young adults' heavy social drinking (cf. Holmila \& Raitasalo, 2005; Nolen-Hoeksema \& Hilt, 2006).

A previous British study on mediation revealed that sex was uncorrelated with the dependent variable (i.e., intentions to get very drunk, Armitage et al., 2002), what implies that there were no sex differences to be mediated. This might be due to convergence in alcohol use between the sexes in the UK, where by now as many or even more teenage girls and young women drink on high levels as their male counterparts (Plant, 2008). ${ }^{4}$ We investigated mediation in Germany, where sex differences in alcohol use are still large (Robert Koch Institut, 2006). Convergence in alcohol consumption, however, may proceed in light of the general recent trends in alcohol use (e.g., Keyes, Grant, \& Hasin, 2008), assumedly in tandem with the progression of gender equality (Bloomfield, Gmel, Neve, \& Mustonen, 2001; Eagly, Wood, \& Diekman, 2000). The results of our study foreshadow that the more women perceive that they are expected to drink heavily, the more they will be willing to do so; the more they are confident to be able to drink large amounts of alcohol the more they will intend to drink heavily and be willing to overdrink in tempting social situations, what may contribute to convergence of alcohol use between the sexes. A qualitative British study (Young, Morales, McCabe, Boyd, \& D'Arcy, 2005) has provided some insight into such processes and illustrates these potential implications of our study. Frequently binge drinking women felt that they were pushed by their male counterparts to drink and that male standards were now applied to judge women as well (cf. subjective norm). Moreover, drinking large quantities was regarded as an ability (cf. selfefficacy), and those women, who "can drink any guy under the table, [were] very very proud of it" (Young et al., 2005,

\footnotetext{
${ }^{3}$ The outcome of alcohol consumption in this re-analysis was represented by blood alcohol concentration including the sex-specific proportion of body water and being adjusted for differences in body weight and the alcohol metabolism during the drinking period. The model (without body weight, but all other parameters held equal to the previous model) fitted the data well, $\chi^{2}=6.98, d f=4, p=.14 ; C F I=$ $1.00, T L I=.97$, RMSEA $=.05$, SRMR $=.02$.

${ }^{4}$ Alcohol consumption of the sexes is beginning to converge through an increase in girls' and women's drinking in some of the alcohol measures used and some of the countries studied, for example in Finland (Bloomfield et al., 2001), Sweden (Bergmark, 2004), the USA (Keyes et al., 2008), and New Zealand (McPherson, Casswell, \& Pledger, 2004), and already seems to have converged in the UK (cf. Plant, 2008). The social role theory (Eagly et al., 2000) may explain such a process: With shifting roles towards gender equality, most sex differences in peoples' expectations about appropriate behavior and in actual behavior should disappear. With regard to alcohol consumption, the convergence hypothesis states that in the course of the emancipation process, in which women have started to move into professions and lifestyles similar to those of men, they should adopt drinking patterns of men as well (cf. Bloomfield et al., 2001).
} 
p. 255). Closing the gap to men means comparably higher risks for women's health given their greater vulnerability to the direct effects of ethanol and to physical diseases at already lower levels of alcohol consumption (cf. NolenHoeksema \& Hilt, 2006). In fact, liver disease has already been increasing amongst young women in the UK (Plant, 2008).

\section{Limitations and Avenues for Further Research}

Findings of our study must be qualified by several limitations. First, some of the self-report measures may be biased by social desirability. Self-reports, however, yield reasonably valid and reliable estimates of alcohol consumption and accuracy can be enhanced by careful data collection (Del Boca \& Darkes, 2003). Confidentiality was guaranteed, and the context of data collection was not threatening or associated with any consequences for the individual, providing little disincentive to respond honestly. Second, the generalizability of results is restricted due to our highly educated sample of young adults. Third, whereas our investigation of mediation is strengthened by drawing on theory, analyzing the model as a whole by means of structural equation modeling, and applying a longitudinal design (MacKinnon, 2008), the temporal sequence within the antecedents of behavior is not warranted, since these were assessed simultaneously. Fourth, the implications for a potential convergence in alcohol consumption are only tentative; future research is needed to determine predictors of change in alcohol use.

The mediation proportion found in this study implies that there is a considerable part of variance left to be explained by other factors. Furthermore, this study does not reflect the process of mediation in its full complexity (e.g., personal resources, multiple contexts, and dynamics between person and environment characteristics have been neglected). Thus, future research should make an effort to broaden the view on the process of mediation of sex on alcohol use and to detect further mediators among psychological and biological variables. Thereby, biological measures should be assessed more directly.

Despite the aforementioned limitations, this study is the first to identify psychological mediators of sex differences in young adults' drinking behaviour based on a well-established theory and a longitudinal approach.

\section{RÉSUMÉ}

\section{Les Différences Entre Les Sexes Quant à La}

\section{Consommation D'alcool Chez Les Jeunes Adultes} Sont-Elles Induites Par Des Variables Psychologiques?

Cette étude analyse, en se basant sur une théorie élargie du comportement planifié, le rôle éventuel de facteurs psychologiques dans les différences entre les sexes quant à la consommation d'alcool. En 2007, des données ont été recueillies auprès de 300 jeunes adultes (dont $49 \%$ de femmes, habitant en milieu urbain et âgés en moyenne de 25 ans) au moyen de questionnaires avant une soirée conviviale le week-end ; ils ont été ensuite interrogés par téléphone sur les boissons qu'ils avaient consommées. Le modèle de médiation multiple a été vérifié au moyen de la modélisation par équations structurelles. Les différences, considérables, entre les sexes quant à la consommation d'alcool ont été partiellement induites par les effets indirects, spécifiques et significatifs de la norme subjective via l'intention et l'auto-efficacité perçue ainsi que via l'intention et la disponibilité comportementale. Le poids de la personne n'a pas été un médiateur significatif. Les limites et implications pour la recherche future sont discutées.

\section{RESUMEN}

\section{¿Existen Variables Psicológicas Que Median Las Diferencias De Género En El Consumo De Alcohol De Adultos Jóvenes?}

Este estudio comprueba la mediación de diferencias de género en el consumo de alcohol aplicando una teoría extendida del comportamiento planificado. En el 2007 fueron colectados 300 cuestionarios de adultos jóvenes (urbanos, edad promedio de 25 años, $49 \%$ mujeres) antes de una ocasión sociable con bebida el fin de semana. Después de este fin de semana estas personas fueron preguntadas por teléfono sobre las bebidas consumidas. El modelo de la mediación múltiple fue analizado mediante el modelo de ecuaciones estructurales. Las considerables diferencias de género que se presentaron en el consumo de alcohol fueron mediadas parcialmente por los efectos indirectos específicos significantes de la norma subjetiva a través de la intención y la autoeficacia percibida mediante la intención y la disposición. El peso corporal no ha sido un mediador significante. Se están discutiendo los límites e implicaciones para la investigación futura.

\section{ZUSAMMENFASSUNG}

\section{Werden Geschlechtsdifferenzen im Alkoholkonsum junger Erwachsener durch psychologische Variablen vermittelt?}

Diese Studie prüft die Mediation von Geschlechtsdifferenzen im Alkoholkonsum anhand einer erweiterten Theorie des geplanten Verhaltens. Es wurden Fragebögen an 300 jungen Erwachsenen (städtisch, mittleres Alter 25 Jahre, 49\% Frauen) in 2007, vor einem geselligen Abend am Wochenende, erhoben; nach dem Wochenende wurden sie in Telefon-Interviews $\mathrm{zu}$ den von ihnen konsumierten Getränken befragt. Das Modell multipler Mediation wurde mittels Strukturgleichungsmodellierung geprüft. Die erheblichen Geschlechtsunterschiede im Alkoholkonsum wurden partiell mediiert durch die signifikanten spezifischen indirekten Effekte der subjektiven Norm über die Intention und der Selbstwirksamkeitserwartung sowohl über die Intention als auch über die Verhaltensbereitschaft. Das Körpergewicht war kein signifikanter Mediator. Grenzen und Implikationen für die zukünftige Forschung werden diskutiert. 


\section{THE AUTHORS}

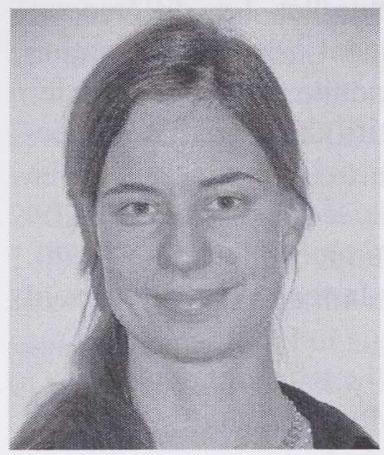

\section{Friederike Zimmermann,}

Dipl. Psych., is a doctoral candidate, and is working at the Psychological Institute, Ruprecht-Karls-University of Heidelberg, Germany. She teaches courses in health psychology and in the psychology of individual differences. Her current research interests include alcohol use among young adults with a focus on the augmentation of socio-cognitive theories and on gender; she has also worked on determinants of health-related behaviors and health-related quality of life.

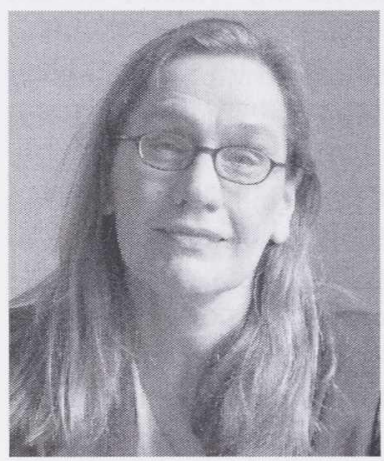

\section{Dr. Monika Sieverding} is a full professor at the Ruprecht-Karls-University in Heidelberg, Germany. She is head of the Department of Gender Studies and Health Psychology at the Psychological Institute. In her research Dr. Sieverding examines psychological factors that influence health-relevant behavior, such as preventive

behavior, cancer screening, alcohol consumption, reckless driving, or fruit and vegetable intake. A special focus of her research deals with gender roles and social norms and their influence on healthrelevant behavior.

\section{GLOSSARY}

Multiple-Path Mediation: Mediation via several consecutive variables. A more complex model (e.g., based on theory as in the present study) may include several such chains.

Bootstrapping in Testing Mediation: The assumption of normally distributed standard errors is likely to be violated when testing indirect effects in mediation analyses (MacKinnon, 2008). The application of bootstrapping permits derivation of standard errors and confidence intervals without imposing the assumption of normal distribution. Rather, the sampling distribution is estimated empirically by obtaining a number of random samples with replacement from the observed dataset.

Mediation proportion: Proportion of the total effect that is due to the (total) indirect effect and thus, is mediated by the intervening variable(s).

\section{REFERENCES}

Ajzen, I. (1991). The theory of planned behavior. Organizational Behavior and Human Decision Processes, 50(2), 179-211.

Allison, P. D. (2003). Missing data techniques for structural equation modeling. Journal of Abnormal Psychology, 112(4), 545-557.

Armitage, C. J., Norman, P., \& Conner, M. (2002). Can the theory of planned behaviour mediate the effects of age, gender and multidimensional health locus of control? British Journal of Health Psychology, 7(3), 299-316.

Bandura, A. (1977). Self-efficacy: Toward a unifiying theory of behavioral change. Psychological Review, 84(2), 191-215.

Bergmark, K. H. (2004). Gender roles, family, and drinking: women at the crossroad of drinking cultures. Journal of family history, 29(3), 293-307.

Bloomfield, K., Gmel, G., Neve, R., \& Mustonen, H. (2001). Investigating gender convergence in alcohol consumption in Finland, Germany, The Netherlands, and Switzerland: A repeated survey analysis. Substance Abuse, 22(1), 3953.

Carey, K. B., Borsari, B., Carey, M. P., \& Maisto, S. A. (2006). Patterns and Importance of Self-Other Differences in College Drinking Norms. Psychology of Addictive Behaviors, 20(4), 385-393

Cialdini, R. B., Reno, R. R., \& Kallgren, C. A. (1990). A focus theory of normative conduct: Recycling the concept of norms to reduce littering in public places. Journal of Personality and Social Psychology, 58(6), 1015-1026.

Collins, S. E., \& Carey, K. B. (2007). The theory of planned behavior as a model of heavy episodic drinking among college students. Psychology of Addictive Behaviors, 21(4), 498-507.

Conner, M., \& Sparks, P. (2005). Theory of planned behaviour and health behaviour. In M. Conner \& P. Norman (Eds.), Predicting health behaviour (pp. 170-222). Buckingham: Open University Press.

Conner, M., Warren, R., Close, S., \& Sparks, P. (1999). Alcohol consumption and the theory of planned behavior: An examination of the cognitive mediation of past behavior. Journal of Applied Social Psychology, 29(8), 1676-1704.

Courtenay, W. H. (2000). Constructions of masculinity and their influence on men's well-being: A theory of gender and health. Social Science \& Medicine, 50(10), 1385-1401.

Del Boca, F. K., \& Darkes, J. (2003). The validity of self-reports of alcohol consumption: state of the science and challenges for research. Addiction, 98, 1-12.

Ditlevsen, S., Christensen, U., Lynch, J., Damsgaard, M. T., \& Keiding, N. (2005). The mediation proportion: A structural equation approach for estimating the proportion of exposure effect on outcome explained by an intermediate variable. Epidemiology, 16(1), 114-120.

Eagly, A. H., Wood, W., \& Diekman, A. B. (2000). Social role theory of sex differences and similarities: A current appraisal. In T. Eckes \& H. M. Trautner (Eds.), The developmental social psychology of gender. (pp. 123-174). Mahwah, NJ, US: Lawrence Erlbaum Associates Publishers.

Francis, J. J., Eccles, M. P., Johnston, M., Walker, A., Grimshaw, J., Foy, R., et al.et al. (2004). Constructing questionnaires based on the theory of planned behavior. A manual for health service researchers. Newcastle.

Gibbons, F. X., Gerrard, M., Blanton, H., \& Russell, D. W. (1998). Reasoned action and social reaction: Willingness and intention as independent predictors of health risk. Journal of Personality and Social Psychology, 74(5), 1164-1180. 
Gibbons, F. X., Gerrard, M., \& Lane, D. J. (2003). A social-reaction model of adolescent health risk. In J. M. Suls \& K. A. Wallston (Eds.), Social psychological foundations of health and illness (pp. 107-036). Oxford, England: Backwell.

Graham, J. W. (2009). Missing data analysis: Making it work in the real world. Annual Review of Psychology, 60, 549-576.

Hingson, R. W., Heeren, T., Zakocs, R. C., Kopstein, A., \& Wechsler, H. (2002). Magnitude of alcohol-related mortality and morbidity among U. S. college students ages 18-24. Journal of Studies on Alcohol, 63(2), 136-144.

Holmila, M., \& Raitasalo, K. (2005). Gender differences in drinking: why do they still exist? Addiction, 100(12), 1763-1769.

Huselid, R. F., \& Cooper, M. L. (1992). Gender roles as mediators of sex differences in adolescent alcohol use and abuse. Journal of Health and Social Behavior, 33(4), 348-362.

Kahler, C. W., Read, J. P., Wood, M. D., \& Palfai, T. P. (2003). Social environmental selection as a mediator of gender, ethnic, and personality effects on college student drinking. Psychology of Addictive Behaviors, 17(3), 226-234.

Keefe, K., \& Newcomb, M. D. (1996). Demographic and psychosocial risk for alcohol use: Ethnic differences. Journal of Studies on Alcohol, 57(5), 521-530.

Keyes, K. M., Grant, B. F., \& Hasin, D. S. (2008). Evidence for a closing gender gap in alcohol use, abuse, and dependence in the United States population. Drug and Alcohol Dependence, 93(1), 21-29.

Kline, R. B. (2005). Structural Equation Modeling. New York: Guilford Press.

Lemle, R., \& Mishkind, M. E. (1989). Alcohol and masculinity. Journal of Substance Abuse Treatment, 6(4), 213-222.

MacKinnon, D. P. (2008). Introduction to statistical mediation analysis. New York: Lawrence Erlbaum Associates.

Mäkelä, P., Gmel, G., Grittner, U., Kuendig, H., Kuntsche, S., Bloomfield, K., et al. (2006). Drinking patterns and their gender differences in Europe. Alcohol and Alcoholism, 41, 8-18.

McPherson, M., Casswell, S., \& Pledger, M. (2004). Gender convergence in alcohol consumption and related problems: Issues and outcomes from comparisons of New Zealand survey data. Addiction, 99(6), 738-748.

Muthén, L. K., \& Muthén, B. O. (2008). Mplus version 5.2 [Computer Software].

Neal, D. J., \& Simons, J. S. (2007). Inference in regression models of heavily skewed alcohol use data: A comparison of ordinary least squares, generalized linear models, and bootstrap resampling. Psychology of Addictive Behaviors, 21(4), 441-452.

Neve, R. J. M., Lemmens, P. H., \& Drop, M. J. (1997). Gender differences in alcohol use and alcohol problems: Mediation by social roles and gender-role attitudes. Substance Use \& Misuse, 32(11), 1439-1459.

Nolen-Hoeksema, S., \& Hilt, L. (2006). Possible contributors to the gender differences in alcohol use and problems. The Journal of General Psychology, 133(4), 357-374.

Norman, P., \& Conner, M. (2006). The theory of planned behaviour and binge drinking: Assessing the moderating role of past behaviour within the theory of planned behaviour. British Journal of Health Psychology, 11(1), 55-70.
Peralta, R. L. (2007). College alcohol use and the embodiment of hegemonic masculinity among European American men. Sex Roles, 56(11), 741-756.

Perkins, H. W. (2002a). Social norms and the prevention of alcohol misuse in collegiate contexts. Journal of Studies on Alcohol, 164-172.

Perkins, H. W. (2002b). Surveying the damage: A review of research on consequences of alcohol misuse in college populations. Journal of Studies on Alcohol, 91-100.

Plant, M. L. (2008). The role of alcohol in women's lives: A review of issues and responses. Journal of Substance Use, 13(3), $155-191$.

Preacher, K. J., \& Hayes, A. F. (2008). Asymptotic and resampling strategies for assessing and comparing indirect effects in multiple mediator models. Behavior Research Methods, 40(3), 879-891.

Rivis, A., \& Sheeran, P. (2003). Descriptive norms as an additional predictor in the theory of planned behaviour: A meta-analysis. Current Psychology: Developmental, Learning, Personality, Social, 22(3), 218-233.

Robert Koch Institut. (2006). Gesundheit in Deutschland [Health in Germany]. Berlin: Robert Koch Institut.

Schermelleh-Engel, K., Moosbrugger, H., \& Müller, H. (2003). Evaluating the fit of structural equation models: Tests of significance and descriptive goodness-of-fit measures. Methods of Psychological Research Online, 8(2), 28-74.

Suls, J., \& Green, P. (2003). Pluralistic ignorance and college student perceptions of gender-specific alcohol norms. Health Psychology, 22(5), 479-486.

Taylor, A. B., MacKinnon, D. P., \& Tein, J.-Y. (2008). Tests of the three-path mediated effect. Organizational Research Methods, $11(2), 241-269$

Waldron, I. (1988). Gender and health-related behavior. In D. S. Gochman (Ed.), Health behavior: Emerging research perspectives. (pp. 193-208): Plenum Press.

Widmark, E. M. P. (1932). Die theoretischen grundlagen und die praktische verwendbarkeit der gerichtlich-medizinischen Alkoholbestimmung [Principles and applications of mediolegal alcohol determination]. Berlin: Urban Schwarzenberg.

Wilsnack, R. W., Vogeltanz, N. D., Wilsnack, S. C., \& Harris, T. R. (2000). Gender differences in alcohol consumption and adverse drinking consequences: Cross-cultural patterns. Addiction, 95(2), 251-265.

Wilsnack, R. W., Wilsnack, S. C., Kristjanson, A. F., VogeltanzHolm, N. D., \& Gmel, G. (2009). Gender and alcohol consumption: Patterns from the multinational GENACIS project. Addiction, 104(9), 1487-1500.

Young, A. M., Morales, M., McCabe, S. E., Boyd, C. J., \& D'Arcy, H. (2005). Drinking like a guy: Frequent binge drinking among undergraduate women. Substance Use \& Misuse, 40(2), $241-267$.

Zimmermann, F., \& Sieverding, M. (2010). Young adults social drinking as explained by an augmented theory of planned behavior: The soles of proto-types, Willingness, and gender. British Journal of Health Psychology, 15, 561581. 